Abstracta Iranicacta Iranica

Revue bibliographique pour le domaine irano-aryen

Volume 31 | 2011

Comptes rendus des publications de 2008

\title{
L'historiographie syriaque. Paris, Geuthner, 2009, 219 p. (Études syriaques 6)
}

Florence Jullien

\section{(2) OpenEdition}

1 Journals

Édition électronique

URL : http://journals.openedition.org/abstractairanica/39650

DOI : 10.4000/abstractairanica.39650

ISSN : 1961-960X

\section{Éditeur :}

CNRS (UMR 7528 Mondes iraniens et indiens), Éditions de l'IFRI

\section{Édition imprimée}

Date de publication : 15 mai 2011

ISSN : 0240-8910

\section{Référence électronique}

Florence Jullien, «L'historiographie syriaque. Paris, Geuthner, 2009, 219 p. (Études syriaques 6) », Abstracta Iranica [En ligne], Volume 31 | 2011, document 206, mis en ligne le 11 octobre 2012, consulté le 04 octobre 2020. URL : http://journals.openedition.org/abstractairanica/39650 ; DOI : https:// doi.org/10.4000/abstractairanica.39650

Ce document a été généré automatiquement le 4 octobre 2020.

Tous droits réservés 


\title{
L'historiographie syriaque. Paris, Geuthner, 2009, 219 p. (Études syriaques 6)
}

\author{
Florence Jullien
}

éd.

Ce volume publié suite à la table ronde annuelle organisée par la Société d'Études syriaques permet d'aborder le genre littéraire historiographique. Deux traditions coexistent malgré l'unification politique réalisée par les conquêtes arabo-musulmanes : l'une syro-occidentale inspirée de la Chronique d'Eusèbe et de ses successeurs, l'autre syro-orientale fondée sur des biographies, à la manière de la tradition historiographique des écoles philosophiques grecques. La tradition syriaque est particulièrement riche en textes historiques produits entre le VI ${ }^{e}$ et le XIII ${ }^{e}$ siècle. Les contributions ici réunies fournissent une approche permettant d'évaluer les liens de ces textes avec l'héritage de la tradition grecque et avec l'historiographie musulmane à laquelle ces sources puisent largement tout en restituant des données parfois totalement disparues.

\section{INDEX}

Thèmes : 6.3. Autres religions 
AUTEURS

FLORENCE JULLIEN

EPHE - Paris 